\title{
Strong and Direct Correlation in Heart Failure Between B-Lines and NT-proBNP Levels
}

\author{
Kalp Yetersizliğinde B-çizgileri ile NT-ProBNP Düzeyleri Arasında Güçlü ve Direkt Korelasyon
}
${ }^{1}$ Hakan Dolgun, ${ }^{2}$ Nurdan Acar, ${ }^{2}$ Engin Ozakin, ${ }^{2}$ Filiz Baloglu Kaya, ${ }^{2}$ Mustafa Emin Canakci, ${ }^{3}$ Ebubekir Arslan, ${ }^{3}$ Turgay Caglayan

${ }^{1}$ Sanliurfa Siverek State Hospital, Emergency Service, Sanliurfa, Turkey

${ }^{2}$ Department of Emergency Medicine, Eskişehir Osmangazi University, Eskisehir, Turkey

${ }^{3}$ Eskişehir City Hospital, Emergency Service, Eskisehir, Turkey
Correspondence:

Nurdan ACAR

Department of Emergency Medicine, Eskişehir Osmangazi University, Eskisehir, Turkey

e-mail: nurdanergun@gmail.com

\section{Abstract}

The aim of the study was to evaluate the compliance of the number of B-lines on focused lung ultrasound with the clinical heart failure classification of the New York Heart Association (NYHA) and NT-proBNP levels in the emergency department. This prospective study was conducted in a tertiary university hospital emergency department. Patients over 18 years of age complaining of shortness of breath or heart failure diagnosis between January 2016 and July 2016. The number of B-lines according to the BLUE point regions was measured. Correlations between the clinical heart failure stage, NT-proBNP level and number of B-lines on ultrasonography were analyzed. Of the 143 patients, $92(64.3 \%)$ were male and $51(35.7 \%)$ were female. The median age was 73.00 (66.00-79.00). There was a very strong correlation between the number of B-lines and NYHA stages for each region $(\mathrm{r}>0.85$ for all variables; $\mathrm{p}<0.001$ for all). There was also a strong and direct correlation between the number of B-lines and the NT-proBNP levels for each region $(r>0.70 ; p<0.001)$. Regarding the shortness of breath numerical score $(r>0.45 ; p<0.001)$, there was an inverse relationship with ejection fraction (EF). The relationship between the EF and BLUE points was moderate, but negative and significant $(\mathrm{p}<0.001)$. NT-proBNP levels, the NHYA classification, and lung ultrasound can be used as a tool in the emergency department for a faster diagnosis and decision-making in lung congestion.

Keywords: Heart failure, $\mathrm{N}$-terminal pro-brain natriuretic peptide, B-lines, Emergency care, Ultrasonography
Çalışmanın amacı, odaklanmış akciğer ultrasonu üzerindeki B-çizgilerinin sayısının, New York Kalp Derneği'nin (NYHA) klinik kalp yetmezliği sınıflaması ve acil serviste NT-proBNP düzeyleriyle ilişkisini değerlendirmekti. Bu ileriye dönük çalışma, bir üçüncü basamak üniversite hastanesinin acil servisinde gerçekleştirildi. Ocak 2016 ile Temmuz 2016 tarihleri arasında nefes darlı̆̆ yakınması veya kalp yetmezliği tanısı olan 18 yaş üstü hastalar çalışmaya alındı. Hastaların BLUE protokolünde belirtilen bölgelere göre B çizgisi sayısı ölçüldü. Klinik kalp yetmezliği evresi, NT-proBNP düzeyi ve akciğer ultrasonografisindeki B-çizgisi sayısı arasındaki ilişkiler analiz edildi. Toplam 143 hastanın 92'si (\% 64,3) erkek, 51'i $(\% 35,7)$ kadındı. Ortanca yaş 73,00 (66,00-79,00) idi. Her bölge için B çizgilerinin sayısı ve NYHA aşamaları arasında çok güçlü bir korelasyon vardı (tüm değişkenler için $r>0.85$; tümü için $\mathrm{p}<0.001)$. Ayrıca her bölge için B çizgilerinin sayısı ile NT-proBNP seviyeleri arasında güçlü ve doğrudan bir korelasyon $\operatorname{vard} 1(r>0.70 ; p<0.001)$. Nefes darlığı sayısal skoru $(r>0.45 ; p<0.001)$ ile ejeksiyon fraksiyonu $(E F)$ arasında ters bir iliski vardı. EF ve BLUE noktaları arasındaki ilişki orta düzeyde, ancak negatif ve anlamlyd $(\mathrm{p}<0.001)$. NT-proBNP seviyeleri, NHYA sinıflandırması ve akciğer ultrasonu, acil serviste akciğer konjesyonunda daha hızlı tanı ve karar verme için bir araç olarak kullanılabilir.

Anahtar Kelimeler: kalp yetersizliği, NT-proBNP, B-çizgileri, akciğer ultrasonu 


\section{Introduction}

In patients with heart failure, abnormal distribution of fluids into the pulmonary vascular bed leads to respiratory failure (1). B-lines observed via sonography are compatible with radiological findings of intravenous fluid volume in the lungs and invasive measurements of pulmonary capillary wedge pressure (2-5).

According to the 2016 European Society of Cardiology (ESC) guidelines, heart failure diagnosis is divided into three categories, based on the ejection fraction (EF), as follows: (1) reduced EF (HFrEF), (2) moderate-reduced EF (HFmrEF), and (3) preserved EF (HFpEF). Based on this classification and the signs and symptoms of heart failure, the use of natriuretic peptide in patients with an EF over $40 \%$ is recommended for class $\mathrm{C}$ diagnoses (level of evidence: IIa) (6).

Studies have shown that high levels of Nterminal pro-brain natriuretic peptide (NTproBNP) are a valuable and consistent measurement when diagnosing heart failure and determining the prognosis (7-9). Therefore, measuring natriuretic peptide levels is recommended for ruling-out $\mathrm{HF}$ $(<300 \mathrm{pg} / \mathrm{mL})$, but not establishing the diagnosis (6-14).

Increased NT-proBNP levels are associated with poor patient outcomes (10). However, NT-proBNP levels are not completely accurate when diagnosing heart failure; this is because comorbidities, such as acute and chronic renal failure, hypertension, myocardial ischemia, dysrhythmia, heart valve diseases, and myocarditis, and other factors, such as age, sex, body weight, and renal function may cause an increase in NTproBNP levels (14). Therefore, many guidelines recommend the use of natriuretic peptide levels for determining prognosis and indicating hemodynamic changes in the diagnosis of heart failure (15-17). Although there are studies in the literature that demonstrate the association between lung ultrasound and the prognosis and treatment of heart failure, there are few studies showing the correlation between NT-proBNP levels and lung ultrasound (18).
Therefore, the aim of the present study was to evaluate the compliance of the number of Blines on focused lung ultrasound with the acute heart failure classification of the New York Heart Association (NYHA) and NTproBNP levels in the emergency department.

\section{Material \& Methods}

\subsection{Setting, location and ethical considerations}

Our study was conducted prospectively in a tertiary university hospital emergency department between January 2016 and July 2016. We included patients over 18 years of age who were admitted to the emergency department complaining of shortness of breath or heart failure diagnosis. We excluded patients who (1) were under 18 years of age, (2) were pregnant, (3) were unable to undergo lung ultrasound, or (4) did not provide informed consent. The local ethics committee approved the study and written informed consent was obtained from all patients prior to participation.

\subsection{Measurement and outcome}

NT-proBNP and cardiac enzyme measurements for all patients were obtained using the Roche Hitachi Cobas e411 electrochemiluminescence immunological test. The maximum value in the reference range for NT-proBNP was $35000 \mathrm{pg} / \mathrm{mL}$.

Ultrasonography was performed by emergency physicians immediately after the examination of the patient and were performed with the "GE" - Vivid E portable ultrasound device [GE Medical Systems (China) CO. Ltd] and 3-5S convex probe. Ultrasonographic measurement points were made according to the BLUE Protocol (2). According to BLUE protocol more than $3 \mathrm{~B}-$ Lines in a segment strongly shows alveolar edema and this finding is specific for acute heart failure. Echocardiography was performed by a single cardiologist using the 3S sector probe of "GE" - Vivid E portable ultrasound device. Heart failure patients divided to three major groups according to Left Ventricular Ejection Fraction (LVEF) 
[EF $\geq 50 \%$; HF with preserved $\mathrm{EF}$ (HFpEF), $\mathrm{EF}<40 \%$; HF with reduced $\mathrm{EF}$ (HFrEF); EF between $40-49 \%$ define as moderately reduced (HFmrEF)]. HFpEF and HFmrEF evaluated with tissue doppler for the diastolic dysfunction

The primary outcome was the correlation of number of B-lines, NYHA stage and NTproBNP level.

\subsection{Sample size calculation}

For the sample size calculation, we considered the Pearson correlation with 0.95 power and a hypothetically low correlation between the clinical heart failure stage and ultrasonographic number of B-lines. The low correlation between them was calculated as 0.30. According to this calculation and a power of 0.95 , a sample size of 138 patients who met the inclusion criteria was deemed appropriate.

\subsection{Statistical analyses}

IBM SPSS Statistics 21.0 (Armonk, NY: IBM Corp.) was used for all statistical analyses. Continuous data are expressed as mean \pm standard deviation (SD) and median (interquartile range [IQR]). Categorical data are expressed as $n$ and percentages (\%). The Shapiro-Wilk test was used to assess the normality of the distribution. The KruskalWallis $\mathrm{H}$ test was used to compare B-lines and NYHA stage among the groups. Spearman correlation coefficients were calculated for variables that did not conform to the normal distribution and were used to determine the direction and magnitude of the correlation between variables. Odds ratios (OR) were used to determine risk factors. A p-value $<0.05$ was considered statistically significant.

\section{Results}

Of the 143 patients included in the study, 92 $(64.3 \%)$ were male and $51(35.7 \%)$ were female. The vital signs and shortness of breath numerical score for all patients are shown in Table 1 . The median age of all patients was 73.00 years $(66.00-79.00$ years $)$.

Table 1. Patient demographics, vital signs, numeric shortness of breath scores and ejection fraction.

\begin{tabular}{|c|c|c|c|}
\hline Parameters & Minimum & Maximum & Median (IQR) \\
\hline Male & 30 & 95 & $72.00(66.00-77.75)$ \\
\hline Female & 51 & 92 & $74.00(67.00-82.00)$ \\
\hline Total & 30 & 95 & $73.00(66.00-79.00)$ \\
\hline Systolic blood pressure (mmHg) & 90 & 220 & $130.0(110.0-150.0)$ \\
\hline Diastolic blood pressure (mmHg) & 50 & 120 & $80.0(70.0-90.0)$ \\
\hline Pulse rate (beats/min) & 54 & 170 & $90.0(80.0-108.0)$ \\
\hline Respiratory rate (breaths/min) & 16 & 44 & $28.0(20.0-32.0)$ \\
\hline Temperature $\left({ }^{\circ} \mathrm{C}\right)$ & 35.0 & 39.1 & $36.0(36.0-36.6)$ \\
\hline Oxygen Saturation (\%) & 58 & 99 & $91.0(85.0-95.0)$ \\
\hline $\begin{array}{c}\text { Numeric Shortness of Breath } \\
\text { Score }\end{array}$ & 1 & 10 & $6.0(3.0-7.0)$ \\
\hline EF & 14 & 60 & $40.0(25.0-50.0)$ \\
\hline
\end{tabular}

We found that coronary artery disease (CAD, $85.3 \%$ ) was the most common disease, according to the disease history of the patients; furthermore, $83.9 \%$ of the patients had hypertension, $51.7 \%$ had diabetes mellitus, $23.1 \%$ had chronic kidney disease, and $19.6 \%$ had chronic obstructive pulmonary disease (COPD). When examining the habits of the patients, it was found that $84(58.7 \%)$ were smokers. There was a significant 
difference in the distribution of patients with CAD and COPD for both males and females ( $p=0.049 ; p<0.001$, respectively). Seventyfour $(60.65 \%)$ of 122 patients with CAD and $27(96.42 \%)$ of 28 patients with COPD were male. Therefore, male sex was found to be an important risk factor for CAD and COPD (OR $=3.89$ and 20.769 , respectively).

The median NT-proBNP level was 10530.19 $\mathrm{pg} / \mathrm{mL}(2285.00-15855.00 \mathrm{pg} / \mathrm{mL})$.

The chest X-ray findings revealed mediastinal enlargement in $110(76.9 \%)$ patients, cardiomegaly in $119(83.2 \%)$ patients, and bilateral hilar edema in $72(50.3 \%)$ patients. There was no consolidation in the lung in 141 (98.6\%) patients; on the other hand, there was consolidation in the right lung in 1 patient $(0.7 \%)$ and left lung in 1 patient $(0.7 \%)$. While pleural fluid was not detected in 69
(48.3\%) patients, it was observed only in the left side in $3(2.1 \%)$ patients and bilaterally in $71(49.7 \%)$ patients.

According to the echocardiographic findings, 140 patients had systolic insufficiency $(97.9 \%)$ and 75 patients had diastolic insufficiency (52.4\%).

There was no significant difference between the number of B-lines measured on lung ultrasound for all measured positions ( $\mathrm{p}=$ 0.998). It was found that there was a homogenous distribution of the median number of lines for the regions (Table 2).

There was a significant difference between the NYHA stage and the number of B-lines, based on the BLUE point regions ( $p<0.001$ for all regions) (Table 2). As the NYHA stage increased, the number of B-lines increased significantly.

Table 2. Relationship between the NYHA stage and the number of B-lines.

\begin{tabular}{|c|c|c|c|c|c|}
\hline \multirow[t]{3}{*}{ Number of B-Lines } & \multicolumn{4}{|c|}{ Median (IQR) } & \multirow{3}{*}{$\mathrm{p}^{*}$} \\
\hline & \multicolumn{4}{|c|}{ NYHA Stage } & \\
\hline & $\begin{array}{l}\text { Stage } 1 \\
(n=25)\end{array}$ & Stage $2(n=53)$ & Stage $3(n=40)$ & $\begin{array}{c}\text { Stage } 4 \\
(n=2)\end{array}$ & \\
\hline $\begin{array}{c}\text { B-Line } \\
\text { Upper Right }\end{array}$ & $0.00(0.00-1.00)$ & $2.00(2.00-3.00)$ & $4.00(4.00-5.00)$ & $7.00(6.00-8.00)$ & $<0.001$ \\
\hline $\begin{array}{c}\text { B-Line } \\
\text { Lower Right }\end{array}$ & $1.00(0.00-1.00)$ & $2.00(1.00-3.00)$ & $4.50(4.00-5.00)$ & $7.00(6.00-7.00)$ & $<0.001$ \\
\hline $\begin{array}{c}\text { B-Line } \\
\text { Lateral Right }\end{array}$ & $1.00(0.50-1.00)$ & $2.00(1.00-3.00)$ & $4.00(4.00-5.00)$ & $7.00(6.00-8.00)$ & $<0.001$ \\
\hline $\begin{array}{c}\text { B-Line } \\
\text { Posterior Right }\end{array}$ & $1.00(0.00-1.00)$ & $2.00(1.50-3.00)$ & $4.00(3.25-5.00)$ & $7.00(6.00-7.00)$ & $<0.001$ \\
\hline $\begin{array}{l}\text { B-Line } \\
\text { Upper Left }\end{array}$ & $0.00(0.00-1.00)$ & $2.00(1.00-3.00)$ & $4.00(3.00-5.00)$ & $7.00(6.00-7.00)$ & $<0.001$ \\
\hline $\begin{array}{c}\text { B-Line } \\
\text { Lower Left }\end{array}$ & $1.00(0.00-1.00)$ & $2.00(1.00-3.00)$ & $4.00(3.00-5.00)$ & $7.00(6.00-7.00)$ & $<0.001$ \\
\hline $\begin{array}{c}\text { B-Line } \\
\text { Lateral Left }\end{array}$ & $1.00(0.00-1.00)$ & $2.00(1.00-3.00)$ & $4.00(3.00-5.00)$ & $7.00(6.00-7.50)$ & $<0.001$ \\
\hline $\begin{array}{c}\text { B-Line } \\
\text { Posterior Left }\end{array}$ & $1.00(0.00-1.00)$ & $2.00(2.00-3.00)$ & $4.00(3.00-5.00)$ & $7.00(6.00-8.00)$ & $<0.001$ \\
\hline
\end{tabular}

NYHA, New York Heart Association; IQR, interquartile range; SD, standard deviation. Bold $\mathrm{p}$ values indicate statistical significance $(\mathrm{p}<0.001)$.

Furthermore, there was a very strong correlation between the number of B-lines and NYHA stages for each region $(r>0.85$ for all variables; $\mathrm{p}<0.001)$. There was also a strong and direct correlation between the number of B-lines and the NT-proBNP levels for each region $(r>0.70 ; p<0.001)$. Regarding the shortness of breath numerical score ( $r>0.45$; $\mathrm{p}<0.001)$, there was an inverse relationship with the EF. The relationship between the EF and BLUE points was moderately negative and significant $(\mathrm{p}<0.001)$ (Table 3$)$. 
Table 3. Correlations between B-lines and NYHA, Numeric Shortness of Breath Score, NT-proBNP levels, and EF.

\begin{tabular}{|c|c|c|c|c|}
\hline Number of B-Lines & NYHA Stage & $\begin{array}{c}\text { Numeric Shortness } \\
\text { of Breath Score }\end{array}$ & NT-proBNP level & $\mathbf{E F}$ \\
\hline $\begin{array}{l}\text { B-Line } \\
\text { Upper Right }\end{array}$ & $0.910 ;<0.001$ & $0.536 ;<0.001$ & $0.798 ;<0.001$ & $\begin{array}{l}-0.514 \\
<0.001\end{array}$ \\
\hline $\begin{array}{l}\text { B-Line } \\
\text { Lower Right }\end{array}$ & $0.905 ;<\mathbf{0 . 0 0 1}$ & $0.511 ;<0.001$ & $0.776 ;<0.001$ & $\begin{array}{l}-0.528 \\
<0.001\end{array}$ \\
\hline $\begin{array}{l}\text { B-Line } \\
\text { Lateral Right }\end{array}$ & $0.881 ;<0.001$ & $0.492 ;<0.001$ & $0.760 ;<0.001$ & $\begin{array}{l}-0.506 \\
<0.001\end{array}$ \\
\hline $\begin{array}{l}\text { B-Line } \\
\text { Posterior Right }\end{array}$ & $0.908 ;<\mathbf{0 . 0 0 1}$ & $0.497 ;<0.001$ & $0.798 ;<0.001$ & $\begin{array}{l}-0.493 \\
<0.001\end{array}$ \\
\hline $\begin{array}{l}\text { B-Line } \\
\text { Upper Left }\end{array}$ & $0.882 ;<0.001$ & $0.457 ;<0.001$ & $0.740 ;<0.001$ & $\begin{array}{l}-0.523 \\
<0.001\end{array}$ \\
\hline $\begin{array}{l}\text { B-Line } \\
\text { Lower Left }\end{array}$ & $0.892 ;<\mathbf{0 . 0 0 1}$ & $0.478 ;<0.001$ & $0.758 ;<0.001$ & $\begin{array}{l}-0.475 \\
<0.001\end{array}$ \\
\hline $\begin{array}{l}\text { B-Line } \\
\text { Lateral Left }\end{array}$ & $0.881 ;<0.001$ & $0.511 ;<0.001$ & $0.779 ;<0.001$ & $\begin{array}{l}-0.458 \\
<0.001\end{array}$ \\
\hline $\begin{array}{l}\text { B-Line } \\
\text { Posterior Left }\end{array}$ & $0.895 ;<\mathbf{0 . 0 0 1}$ & $0.492 ;<0.001$ & $0.789 ;<0.001$ & $\begin{array}{l}-0.484 \\
<0.001\end{array}$ \\
\hline
\end{tabular}

There were no significant differences between the presence of systolic insufficiency and the number of B-lines, based on the BLUE point regions $(p>0.05$ for all). However, the number of B-lines was higher in patients with systolic insufficiency. There was a significant difference between diastolic insufficiency and the number of B-lines, based on the BLUE point regions ( $p<0.001$ for all). The number of B-lines was higher in patients with diastolic insufficiency than patients without diastolic insufficiency.

\section{Discussion}

The NYHA clinical heart failure classification assesses the functional status of patients. The prognostic importance and sensitivity of NTproBNP levels in the early diagnosis of heart failure has previously been reported (19). In our study, we found that the NYHA clinical heart failure classification, NT-proBNP levels, and the number of B-lines on lung ultrasound were highly compatible in patients aged 18 years and older who presented to the emergency department complaining of shortness of breath.

There was a significant difference between the number of B-lines and the NYHA stage; the
NYHA stage increased as the number of Blines increased ( $p<0.001$ for all regions). These data were similar to those reported in previous studies $(20,21)$.

Furthermore, we found that there was a significant difference between the number of B-lines and the NT-proBNP level; that is, NTproBNP levels increased as the number of $\mathrm{B}$ lines increased ( $p<0.001$ for all regions). Murthy et al. reported a similar relationship between these parameters (22). There are different interpretations regarding the number of B-lines in the literature. Generally, the presence of $\geq 30 \mathrm{~B}$-lines in all areas indicates an increase in mortality; we showed that NYHA stages 3 and 4 had more than 30 Blines, on average (23). On the other hand, a lower number of B-lines is known to be associated with a lower mortality rate (23). Therefore, morbidity can be estimated using early ultrasonography (24). In a previous evaluation of NT-proBNP and lung ultrasound, the sensitivity, specificity, negative predictive value (NPV), and positive predictive value (PPV) increased in 1005 patients (25). The validity of ultrasound is significant in the diagnosis of acute decompensated heart failure in patients presenting with dyspnea. Similarly, Gallard et 
al. investigated clinical findings, chest radiography, and cardiopulmonary ultrasonography, revealing that the sensitivity, specificity, NPV, and PPV for cardiopulmonary ultrasound were better than all other conditions (26). Furthermore, Liu et al. reported that the number of B-lines was significantly higher in heart failure patients with pulmonary infection (27).

The vital signs of the patients included in the study were the same as those previously evaluated by Sartini et al. in a study of 255 patients. They found a mean systolic blood pressure of $131.00 \pm 22.00 \mathrm{mmHg}$, mean diastolic blood pressure of $72.00 \pm 14.00$ $\mathrm{mmHg}$, mean pulse rate of $89.00 \pm 20.00$ beats $/ \mathrm{min}$, average breath number of $20.00 \pm$ 9.00 breaths $/ \mathrm{min}$, and an average fingertip oxygen saturation of $93.00 \pm 10.00 \%$ (28). These values were similar to those reported in the present study.

Regarding the laboratory values, the median NT-proBNP level was $10.530 \mathrm{pg} / \mathrm{mL}$ (2.285$15.855 \mathrm{pg} / \mathrm{mL}$ ) in our study. According to a previous study, the median NT-proBNP level of patients with acute decompensation was $5.682 \mathrm{pg} / \mathrm{mL} \quad(1.728-11.020 \mathrm{pg} / \mathrm{mL})$ (29). Furthermore, Gallard et al. reported a median NT-proBNP level of $4.337 \mathrm{pg} / \mathrm{mL}$ (2.064$10.827 \mathrm{pg} / \mathrm{mL})(26)$.

Echocardiographic findings revealed that 140 $(97.9 \%)$ patients had systolic insufficiency, while $75(52.4 \%)$ patients had diastolic insufficiency. Similar frequencies of systolic and diastolic insufficiency have been reported in the literature (30). Our study may have yielded differences due to the small sample size $(\mathrm{n}=143)$. Furthermore, the median EF was $40.0 \%(25.0-50.0)$, and this value aligned with that found in a previous study (18). Increasing the number of patients in the study group will confirm the relationships between the number of B-lines and systolic insufficiency, mitral insufficiency, and tricuspid insufficiency on echocardiography. In addition, there are studies on the use of lung ultrasound not only in heart failure but also in other conditions that cause congestion, especially in kidney failure. It is thought that its use in different situations will increase in terms of determining the patient's volume status and showing lung congestion $(31,32)$.

According to the results of our study, the number of B-lines on lung ultrasound was highly correlated with the NYHA clinical stage and blood NT-proBNP level. In our study, the number of B-lines was similar to the direct $\mathrm{X}$-ray findings associated with pulmonary congestion.

It should be remembered that ultrasonography is a noninvasive, practical, and fast method that can be used safely in the emergency department.

\subsection{Limitations}

This study has some limitations that should be addressed. First, the study was a single-center study with a sample size of 143 patients. We included patients complaining of shortness of breath, regardless of other signs of pulmonary edema. Shortness of breath is a subjective finding and difficulties in defining the diagnosis of heart failure may have led to bias in patient selection. However, since the main aim of our study was to evaluate the consistency of NYHA stages and blood NTproBNP levels with the number of B-lines on lung ultrasound, the determination of the inclusion criteria, as such, ensured that NYHA stage 1 and 2 patients were not skipped. The patients with clinical features of heart failure were analyzed and patients with clinical conditions, other than heart failure on lung ultrasound, were excluded. Due to the difficulty in making the diagnosis of heart failure, high sensitivity to patient selection may have caused this group to be excluded from the study. The follow-up values of the patients were not examined in the study and their evaluations at the time of admission were analyzed. Future studies should include more patients and investigate the effectiveness of different combinations of NT-proBNP levels, NYHA class, and lung ultrasound on the clinical decision-making process, which are evaluated with acute heart failure in emergency conditions.

\subsection{Conclusions}

In this study, we revealed that there is a correlation between the blood NT-proBNP 
levels, the NYHA clinical heart failure classification stages and the number of B-lines in patients with heart failure. Therefore, when patients with heart failure report to the emergency department complaining of shortness of breath or other heart failurerelated complications, ultrasonography can

\section{REFERENCES}

1. Gheorghiade M, Filippatos G, De Luca L, Burnett J. Congestion in acute heart failure syndromes: an essential target of evaluation and treatment. $\mathrm{Am} \mathrm{J}$ Med 2006;119:S3-10.

2. Lichtenstein DA, Meziere GA. Relevance of lung ultrasound in the diagnosis of acute respiratory failure: the BLUE protocol. Chest 2008;134:11725 .

3. Jambrik Z, Monti S, Coppola V, Agricola E, Mottola G, Miniati M, et al. Usefulness of ultrasound lung comets as a nonradiologic sign of extravascular lung water. Am $J$ Cardiol 2004;93:1265-70.

4. Agricola E, Bove T, Oppizzi M, Marino G, Zangrillo A, Margonato A, et al. "Ultrasound comet-tail images": a marker of pulmonary edema: a comparative study with wedge pressure and extravascular lung water. Chest 2005; 127:1690-5.

5. Agricola E, Picano E, Oppizzi M, Pisani M, Meris A, Fragasso G, et al. Assessment of stress-induced pulmonary interstitial edema by chest ultrasound during exercise echocardiography and its correlation with left ventricular function. $J \mathrm{Am}$ Soc Echocardiogr 2006;19:457-63.

6. Ponikowski P, Voors AA, Anker SD, Bueno H, Cleland JGF, Coats AJS, et al.; ESC Scientific Document Group. 2016 ESC Guidelines for the diagnosis and treatment of acute and chronic heart failure: The Task Force for the diagnosis and treatment of acute and chronic heart failure of the European Society of Cardiology (ESC)Developed with the special contribution of the Heart Failure Association (HFA) of the ESC. Eur Heart $J$ 2016;18:891-975

7. Felker GM, Hasselblad V, Hernandez AF, O'Connor CM. Biomarker-guided therapy in chronic heart failure: a meta-analysis of randomized controlled trials. Am Heart $J$ 2009; 158:422-30.

8. Januzzi JL Jr, Peacock WF, Maisel AS, Chae CU, Jesse RL, Baggish AL, et al. Measurement of the interleukin family member ST2 in patients with acute dyspnea: results from the PRIDE (Pro-Brain Natriuretic Peptide Investigation of Dyspnea in the Emergency Department) study. J Am Coll Cardiol 2007;50:607-13.

9. Maisel AS, Krishnaswamy P, Nowak RM, McCord J, Hollander JE, Duc P, et al.; Breathing evaluate the severity of heart failure during the early period. It is recommended that physicians working in emergency departments use lung ultrasound to evaluate patient complaints related to heart failure.

- 5th Eurasian Congress on Emergency Medicine \& 12th Turkish Emergency Medicine Congress, November $10-13$, 2016, Antalya /Turkey

Not Properly Multinational Study Investigators. Rapid measurement of B-type natriuretic peptide in the emergency diagnosis of heart failure. $N E n g l$ $J$ Med 2002;347:161-7.

10. Sachdeva A, Horwich TB, Fonarow GC. Comparison of usefulness of each of five predictors of mortality and urgent transplantation in patients with advanced heart failure. $\mathrm{Am} \mathrm{J}$ Cardiol 2010;106:830-5.

11. Januzzi JL Jr, Camargo CA, Anwaruddin S, Baggish AL, Chen AA, Krauser DG, et al. The Nterminal Pro-BNP investigation of dyspnea in the emergency department (PRIDE) study. $\mathrm{Am} \mathrm{J}$ Cardiol 2005;95:948-54.

12. Palmer SC, Yandle TG, Nicholls MG, Frampton CM, Richards AM. Regional clearance of aminoterminal pro-brain natriuretic peptide from human plasma. Eur J Heart Fail 2009;11:832-9.

13. van Kimmenade RR, Januzzi JL Jr, Bakker JA, Houben AJ, Rennenberg R, Kroon AA, et al. Renal clearance of B-type natriuretic peptide and amino terminal pro-B-type natriuretic peptide: a mechanistic study in hypertensive subjects. $J \mathrm{Am}$ Coll Cardiol 2009;53:884-90.

14. Januzzi JL, Chen-Tournoux AA, Moe G. Aminoterminal pro-B-type natriuretic peptide testing for the diagnosis or exclusion of heart failure in patients with acute symptoms. Am $J$ Cardiol 2008;101:S29-38.

15. Cleland JG, McDonagh T, Rigby AS, Yassin A, Whittaker T, Dargie HJ; National Heart Failure Audit Team for England and Wales. The national heart failure audit for England and Wales 20082009. Heart 2011;97:876-86.

16. Zoghi M, Cavusoglu Y, Yilmaz MB, Nalbantgil S, Eren M, Mebazaa A. Practical approach to acute heart failure with algorithms [Article in Turkish]. Anadolu Kardiyol Derg 2009;9:436-46.

17. Lam CS, Burnett JC, Costello-Boerrigter L, Rodeheffer RJ, Redfield MM. Alternate circulating pro-B-type natriuretic peptide and Btype natriuretic peptide forms in the general population. J Am Coll Cardiol 2007;49:1193-202.

18. Glöckner E, Christ M, Geier F, Otte P, Thiem U, Neubauer S, et al. Accuracy of Point-of-Care BLine Lung Ultrasound in Comparison to NTProBNP for Screening Acute Heart Failure. Ultrasound Int Open 2016;2:E90-2. 
19. Peacock WF 4th. The B-type natriuretic peptide assay: a rapid test for heart failure. Cleve Clin J Med 2002;69:243-51.

20. Aggarwal M, Gupta M, Vijan V, Vupputuri A, Chintamani S, Rajendran B, et al. Use of Lung Ultrasound For Diagnosing Acute Heart Failure in Emergency Department of Southern India. J Clin Diagn Res 2016;10:TC05-8.

21. Coiro S, Porot G, Rossignol P, Ambrosio G, Carluccio E, Tritto I, et al. Prognostic value of pulmonary congestion assessed by lung ultrasound imaging during heart failure hospitalisation: A two-centre cohort study. Sci Rep 2017;7:43972.

22. Sudharshana Murthy KA, Ashoka HG, Aparna AN. Evaluation and comparison of biomarkers in heart failure. Indian Heart J 2016;68:S22-8.

23. Coiro S, Rossignol P, Ambrosio G, Carluccio E, Alunni G, Murrone A, et al. Prognostic value of residual pulmonary congestion at discharge assessed by lung ultrasound imaging in heart failure. Eur J Heart Fail 2015;17:1172-81.

24. Gargani L, Pang PS, Frassi F, Miglioranza MH, Dini FL, Landi $\mathrm{P}$, et al. Persistent pulmonary congestion before discharge predicts rehospitalization in heart failure: a lung ultrasound study. Cardiovasc Ultrasound 2015; 13:40.

25. Pivetta E, Goffi A, Lupia E, Tizzani M, Porrino G, Ferreri E, et al.; SIMEU Group for Lung Ultrasound in the Emergency Department in Piedmont. Lung ultrasound-implemented diagnosis of acute decompensated heart failure in the ED: A SIMEU Multicenter Study. Chest 2015; 148:202-10.

26. Gallard E, Redonnet JP, Bourcier JE, Deshaies D, Largeteau N, Amalric JM, et al. Diagnostic performance of cardiopulmonary ultrasound performed by the emergency physician in the management of acute dyspnea. Am J Emerg Med 2015;33:352-8.

27. Liu ZP, Zhang Y, Bian H, He XR, Zhou YJ, Wang $\mathrm{LJ}$, et al. Clinical application of rapid B-line score with lung ultrasonography in differentiating between pulmonary infection and pulmonary infection with acute left ventricular heart failure. Am J Emerg Med 2016;34:278-81.

28. Sartini S, Frizzi J, Borselli M, Sarcoli E, Granai C, Gialli V, et al. Which method is best for an early accurate diagnosis of acute heart failure? Comparison between lung ultrasound, chest X-ray and NT pro-BNP performance: a prospective study. Intern Emerg Med 2017;12:861-9.

29. Vodovar N, Séronde MF, Laribi S, Gayat E, Lassus J, Boukef R, et al.; GREAT Network. Posttranslational modifications enhance NT-proBNP and BNP production in acute decompensated heart failure. Eur Heart $J$ 2014;35:3434-41.

30. Nagueh SF, Appleton CP, Gillebert TC, Marino PN, Oh JK, Smiseth OA, et al. Recommendations for the evaluation of left ventricular diastolic function by echocardiography. $J \mathrm{Am}$ Soc Echocardiogr 2009;22:107-33.

31. Giannese D, Puntoni A, Cupisti A, Morganti R, Varrichio E, D'Alessandro C, et al. Lung ultrasound and BNP to detect hidden pulmonary congestion in euvolemic hemodialysis patients: a single centre experience. BMC Nephrol 22, 36 (2021).
32. Ngoh CLY, Teng HL, Chua YT, Leo CCH, Wong WK. Comparison between lung ultrasonography and current methods for volume assessment in Asian chronic hemodialysis patients. Hemodial Int. 2020;24:516-527. 